\title{
Influence of fertilizer placement on yield and protein composition in spring malting barley
}

\author{
E. Johansson ${ }^{1,3 *}$, L. Haby ${ }^{2,4}$, M. L. Prieto-Linde ${ }^{1,3}$, and S.-E. Svensson ${ }^{2,4}$
}

${ }^{I}$ Department of Crop Sciences. The Swedish University of Agricultural Sciences, SE-230 53 Alnarp, Sweden. ${ }^{2}$ Department of Landscape Management and Horticultural Technology, The Swedish University of Agricultural Sciences, SE-230 53 Alnarp, Sweden. ${ }^{3}$ Department of Plant Breeding, The Swedish University of Agricultural Sciences, SE-230 53 Alnarp, Sweden. ${ }^{4}$ Department of Biosystems and Technology, The Swedish University of Agricultural Sciences, SE-230 53 Alnarp, Sweden. "Corresponding author:Eva.Johansson@slu.se

\begin{abstract}
Soil type and starter fertilizer treatments are known to influence yield, grain protein concentration and grain protein composition in malting barley (Hordeum vulgare L.) . Combi drilling of spring sown cereal crops has become more popular recently. Depending on the type of combi drill coulter, the fertilizers are placed differently in relation to the seed (e.g. below or beside) and the placement might influence the nitrogen availability. Thus, the aim was to evaluate if and how fertilizer placement by using different coulter types, influenced grain yield, protein concentration and protein composition in spring malting barley.

Fertilizer placement beside and deeper than the sown seed (Väderstad Rapid Combi coulter) resulted in increased emergence (15\%?) 20 days after sowing, and increased yield at normal seed rate compared to when the fertilizer was placed just below the sown seed (Tume Nova Combi coulter). Fertilizer placement just below the sown seed led to an increased protein polymerisation compared to fertilizer placement beside and deeper than the sown seed. Nitrogen fertilization led to an increased yield, grain protein concentration, amount of SDS-extractable and -unextractable proteins and small monomeric proteins compared to no nitrogen fertilization.

To conclude, nitrogen rate correlated positively with amount of most protein types, while close placement/ availability of nitrogen correlated with protein polymerisation. For grain yield, fertilizer placement just below the sown seeds was negative. Thus, placement of nitrogen might influence the quality of the barley grain for malting purposes.
\end{abstract}

Keywords: Combi drilling, coulter type, fertilizer placement, protein composition, protein concentration, yield

Abbreviations: LPP-large polymeric protein; SPP-smaller polymeric protein; LMP-large monomeric protein; SMPsmaller monomeric protein; TOTE-Total amount SDS-extractable proteins; TOTU-Total amount SDS-unextractable protein; UPP-Total unextractable polymeric protein in the total polymeric protein; LargeUPP-Large unextractable polymeric protein in the total large polymeric protein 


\section{Introduction}

Combi drilling of spring sown cereal crops in southern Sweden is an increasing phenomenon (Haby, 2006). Combi drilling results in increased nutrient use efficiency, thereby often resulting in higher grain yields. Also, time is often saved as one person is both sowing and fertilizing at the same time, compared to when conventional drilling equipment is used (Haby, 2006). However, combi drilling requires a relatively high pulling force leading to the need of large heavy tractors and high diesel consumption (Emgardsson, 2004a). Since some years, combi drilling machines with a new type of coulters are available on the market, e.g. Tume Nova Combi. Using this combi drilling equipment, the fertilizer is placed about $2 \mathrm{~cm}$ below or together with the cereal grain with a combined seed/fertilizer coulter. The normal Scandinavian combi drilling technique, instead place the fertilizer $6 \mathrm{~cm}$ beside and $3 \mathrm{~cm}$ deeper than the grain, using separate seed and fertilizer coulters, e.g. Väderstad Rapid Combi (Haby, 2006). The fertilizer placement just below the cereal grain with only one coulter would lead to the need of lower pulling forces compared to conventional combi drilling with separate coulters where the fertilizer is placed beside and deeper than the cereal grain (Emgardsson, 2004b).

Changes in fertilizer placement in relation to the sown wheat grain might, however, influence as well yield as the protein concentration and composition in the mature cereal grains of the crop (Jacobsen et al., 1997). Timing of fertilizer supply as well as availability of nitrogen in the soil has been shown to influence yield and protein quality in wheat (Johansson et al., 2004; 2013; Farrer et al., 2006, Malik et al., 2011; 2013a). In spring malting barley (Hordeum vulgare L.), soil and starter fertilizer, as well as temperature regimes have been shown important for yield, protein concentration and composition and also for break-down rates of proteins during grain germination (Malik et al., 2012; 2013b). However, a too close placement of the fertilizer in relation to the sown cereal grain is well known to burn the coming roots if the field conditions are dry when the grain is germinating (Malhi et al., 2001). Fertilizer placement resulting in burning of roots in germinating grains might lead to a decreased number of plants per square meter, uneven growing and maturation of the plants on the field and decreased yield (Deibert et al., 1985; Radford et al., 1989). Changes in protein concentration and composition influence the quality of the mature cereals (Johansson and Svensson, 1999; 2013; McKenzie et al., 2005; JinXin et al., 2006; Malik et al., 2013a). As protein composition in spring malting barley was also found to influence break-down rates of proteins during germination, protein composition is most likely an important factor determining both beer quality and next generation of plants (Malik et al., 2012; 2013c). In bread wheat, a high protein concentration with "the right" protein composition is of importance for a good bread-making quality (e.g. Johansson et al., 2001). In malting barley, also grain protein concentration and composition are known to influence the malt quality. The grain protein concentration of malting barley should definitively not be too high (Eagles et al., 1995; JinXin et al., 2006). Specific protein components such as $\mathrm{D}$ hordeins, relations between $\mathrm{B}$ and $\mathrm{D}$ hordeins and $\mathrm{Z}$ proteins have been found to relate to beer quality (Peltonen et al., 1994; Howard et al., 1996; Evans and Hejgaard, 1999; Evans et al., 1999; Kaneko et al., 1999). Relations between farming conditions, yield and protein quality and malt and beer quality are scarce due to limited number of studies.

The aim of the present study was to investigate the influences of placement of fertilizer, by the use of two different types of coulters, on the yield, and grain protein concentration and composition of field grown spring malting barley. In order to evaluate the reasons for differences in yield and protein quality in different treatments, also seed emergence was evaluated in the different plots. 


\section{Material and Methods}

\subsection{Plant material and field trial details}

The plant material consisted of the spring malting barley cultivar, Pasadena (Scandinavian Seeds, Lidköping, Sweden). The field experiment in this investigation was carried out in 2005 at the experimental station, Lönnstorp, of the Swedish University of Agricultural Sciences, Alnarp, in the South of Sweden. Two different seed rates were used, 160 and $200 \mathrm{~kg}$ per ha, in order to investigate if an increased seed rate had an influence on yield, and grain protein concentration and composition in relation to used seed coulter.

One fertilizer rate was applied; $367 \mathrm{~kg} \mathrm{~N} 27 / \mathrm{ha}$ (99 $\mathrm{kg} \mathrm{N} / \mathrm{ha}$ ), using both the types of seed coulters, Väderstad Rapid Combi - placing the fertilizer next to and deeper than the cereal grain, and Tume Nova Combi - placing the fertilizer $2 \mathrm{~cm}$ below the cereal grain. As control plots, the malting barley was sown with both the combi drill machines but with no fertilizer application at all. The fertilizer used was N27 (Yara AB, Landskrona, Sweden) due to the already high amount of $\mathrm{P}$ and $\mathrm{K}$ in the soil at the experimental field.

The field experiment consisted of five blocks (replications) and within each block six different treatments (coulter $\mathrm{x}$ seed rate $\mathrm{x}$ nitrogen application) were totally randomly lumped. Each treatment block, inside the full block was $4 \times 24 \mathrm{~m}$ and the harvest was carried out inside each of the treatment blocks, with a size of $1.6 \times 15.80 \mathrm{~m}$.

\subsection{Emergence}

Emergence was counted 20 days after sowing as the number of emerged plants. For each treatment, in each block, the plants were counted within one meter of one row in four places within the treatment and block. In order to get the number of plants per square meter, the number of plants per row meter was multiplied with 8 .

\subsection{Protein analyses}

Total protein concentration was determined using NIR calibrated against Kjeldahl analyses (ICC standard method no 105/1, 1980). Amount and size distribution of polymeric protein was analysed according to Kuktaite et al. (2000), applying size exclusion-high performance liquid chromatography (SE-HPLC) with two-step extraction procedure (Gupta et al., 1993). The first step in this method extracts the proteins soluble in dilute sodium dodecyl sulphate (SDS), whilst the second extract contains proteins soluble only after sonication.

First extraction; $16.5 \mathrm{mg}$ of whole grain flour were suspended in $1.5 \mathrm{ml} 0.5 \%$ SDS-phospate buffer $(\mathrm{pH}$ 6.9) and vortexed for $10 \mathrm{~s}$. Samples were then stirred for $5 \mathrm{~min}$ at $2000 \mathrm{rpm}$ and centrifuged for $30 \mathrm{~min}$ at $10000 \mathrm{~g}$ to obtain the supernatant protein. Second extraction; the pellet was subsequently resuspended in SDS buffer as above and sonicated in an ultrasonic disintegrator (Soniprep 150, Tamro, Mölndal, Sweden) for $45 \mathrm{~s}$, amplitude 5 , fitted with a $3 \mathrm{~mm}$ exponential microtip. Thereafter the samples were centrifuged ( 30 min, $10000 \mathrm{~g}$ ) to obtain a supernatant of proteins.

The extracts were filtered through $0.45 \mu \mathrm{m}$ filters (Millipore, Durapore Membrane Filters) before run on the HPLC. SE-HPLC analyses were performed on a Waters HPLC system using a BIOSEP SEC4000 Phenomenex column. Separation was achieved in $30 \mathrm{~min}$ by loading $20 \mu \mathrm{l}$ of sample into an eluent of $50 \%(\mathrm{v} / \mathrm{v})$ acetonitrile and water containing $0.1 \%$ $(\mathrm{v} / \mathrm{v})$ trifluoroacetic acid (TFA) at a flow rate of 0.2

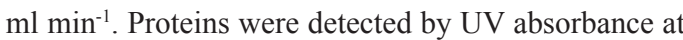
$210 \mathrm{~nm}$. The SE-HPLC chromatograms were divided into four sections with decreasing molecular size; large polymeric proteins (LPP), smaller polymeric proteins (SPP), large monomeric proteins (LMP), smaller monomeric proteins (SMP) (Figure 1; Johansson et al., 2004). Molecular weight range and specific protein composition of the proteins within the SE-HPLC chromatograms have been described by Larroque et al. (1996). 


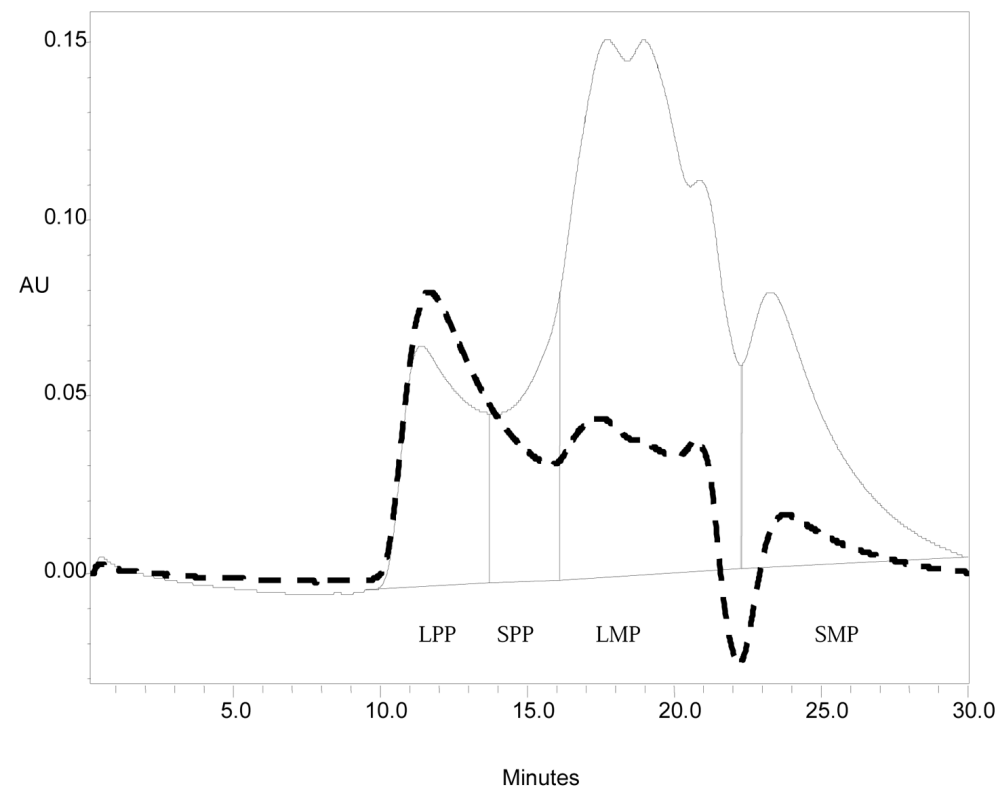

Figure 1. Exemple of SE-HPLC chromatograms of SDS-extractable (---) and SDS-unextractable (-) proteins. The chromatograms are divided into four parts containing large polymeric proteins (LPP), smaller monomeric proteins (SPP), large monomeric proteins (LMP), and smaller monomeric proteins (SMP). AU=absorbance units of the UV detector.

Areas of the different parts were calculated and used as measurements of amounts of the different protein types. The percentages of total unextractable polymeric protein in the total polymeric protein (\%UPP), and large unextractable polymeric protein in the total large polymeric protein (\%LargeUPP) were calculated (Johansson et al., 2005). Also, the TOTE (Total amount extractable protein $=$ SDSextractable $\mathrm{LPP}+\mathrm{SPP}+\mathrm{LMP}+\mathrm{SMP}$ ), TOTU (Total amount unextractable protein $=$ SDS-unextractable $\mathrm{LPP}+\mathrm{SPP}+\mathrm{LMP}+\mathrm{SMP}$ ) were calculated.

For the SE-HPLC analyses, at least two replicates were analysed from each cultivar, nitrogen treatment and coulter.

\subsection{Statistical analyses}

Statistical Analyses System, MS Excel procedures and programs were used for data analyses. Evaluation of the data was carried out using Spearman rank correlations, and analyses of variance (ANOVA; SAS Inst. Inc, Cary, North Carolina). ANOVA was carried out considering cultivar and fertilizer rate as a separate environment and random variable. Yield, protein concentration and protein factors were considered as fixed variables. For comparison of yield and emergence, when different coulter and seed rate was used the analyses of variance was followed by a REGWQ-test at the 5\%-level. For comparisons of protein factors the analysis of variance was followed by a LSD (0.05) test (SAS Inst. Inc, Cary, North Carolina). 


\section{Results}

\subsection{Yield}

Analyses of variance showed a significant relationship between nitrogen application and yield. Also the interaction between nitrogen application and the coulter as well as the nitrogen application and the seed rate showed significant relationship with the yield (Table 1). The application of nitrogen led to an increase in yield compared to no nitrogen applied, while no general increase in yield was found due to seed rate (Table 2). The yield was increased by the use of the Väderstad Rapid coulter compared to the use of the Tume Nova coulter at normal seed rate. No significant differences were found in yield when the different coulters were used at increased seed rate (Table 2).

\subsection{Emergence}

Anova analyses did not indicate a significant difference in emergence 20 days after sowing when the different coulters were used (Table 1). However, comparisons of means showed that the use of the Väderstad Rapid coulter led to an increase in emergence compared to the use of the Tume Nova coulter when fertilizer was applied (Table 2). Also, a high seed rate was found to increase the rate of emerging plants 20 days after sowing compared to normal seed rate when the Väderstad Rapid coulter was used for sowing (Table $2)$. No significant differences in emergence were found when nitrogen was applied compared to when no nitrogen was applied (Table 2).

\subsection{Protein concentration}

The analyses of variance showed a significant relationship between grain protein concentration and nitrogen application as well as for the interaction between seed rate and nitrogen application (Table 1). The grain protein concentration was increased by the use of nitrogen application in comparison with no nitrogen applied (Table 2).
3.4. Relationships between protein concentration and protein composition parameters

A significant and positive Spearman rank correlation was found among protein concentration, relative amount of total SDS-extractable proteins (TOTE; $p<0.5)$ and relative amount of SDS-unextractable proteins (TOTU; $p<0.05$ ). The background of this positive correlation was a positive correlation among protein concentration and SDS-extractable large polymeric proteins (eLPP; $p<0.1$ ), SDS-extractable large monomeric proteins (eLMP; $p<0.05$ ), SDSunextractable large polymeric proteins (uLPP; $p<0.5$ ), SDS-unextractable smaller polymeric proteins (uSPP; $p<0.5)$ and SDS-unextractable large monomeric proteins (uLMP; $p<0.05$ ).

\subsection{Protein composition parameters}

Analyses of variance showed significant relationships among \%LargeUPP, \%UPP and used coulter. Also, a relationship was found among TOTE, \%LargeUPP and seed rate as well as among TOTE, TOTU, \%LargeUPP, SMP and nitrogen application rate (Table 1). Significant relationships were also found among several of the protein factors and interactions between coulter, seed rate and nitrogen application (Table 1).

Mean values showed a significant increase in TOTU, $\%$ LargeUPP and \%UPP, with the Tume Nova coulter used compared to when the Väderstad Rapid coulter was used (Table 2). For the other protein parameters no clear general influence of coulter on amounts could be detected. High seed rate led to a decrease in TOTE compared to normal seed rate (Table 2). For the rest of the protein factors, an increase in seed rate led to an increased relative amount in the protein when the Väderstad Rapid coulter was used while the increase in seed rate led to a decrease in the protein when the Tume Nova coulter was used (Table 2).

The use of nitrogen application led to higher TOTE and TOTU compared to no nitrogen applied (Table 2). 
Table 1. Mean squares from analyses of variance (ANOVA)

\begin{tabular}{llllllllll}
\hline Sorce & DF & Yield & Emerg & Prot & $\begin{array}{l}\text { TOTE } \\
\left(10^{14}\right)\end{array}$ & $\begin{array}{l}\text { TOTU } \\
\left(10^{13}\right)\end{array}$ & $\begin{array}{l}\text { \%LargeUPP } \\
\left(10^{-3}\right)\end{array}$ & $\begin{array}{l}\text { \%UPP } \\
\left(10^{-3}\right)\end{array}$ & $\begin{array}{l}\text { SMP } \\
\left(10^{13}\right)\end{array}$ \\
\hline $\mathrm{C}^{\mathrm{a}}$ & 1 & 1.13 & 37.5 & 0.54 & 0.00 & 4.44 & $6.58^{* *}$ & $7.08^{* * *}$ & 0.03 \\
$\mathrm{~S}^{\mathrm{b}}$ & 1 & 10.8 & 11.6 & 0.24 & $1.23^{*}$ & 0.23 & $2.21^{*}$ & 0.18 & 0.49 \\
$\mathrm{~N}^{\mathrm{c}}$ & 1 & $44.5^{* * *}$ & 0.00 & $4.81^{*}$ & $1.8^{* * *}$ & $15.4^{* * *}$ & $1.90^{* *}$ & 0.00 & $11.1^{* * *}$ \\
$\mathrm{C}^{*} \mathrm{~S}$ & 3 & 3.99 & 19.8 & 0.28 & 0.02 & $3.59^{*}$ & $6.51^{* * *}$ & $6.03^{* * *}$ & 0.57 \\
$\mathrm{C}^{*} \mathrm{~N}$ & 3 & $15.3^{* * *}$ & 16.9 & 1.79 & 0.02 & $3.63^{* * *}$ & $6.51^{* * *}$ & $6.22^{* * *}$ & 0.39 \\
$\mathrm{~S}^{*} \mathrm{~N}$ & 2 & $22.2^{* *}$ & 7.80 & $2.65^{*}$ & $6.18^{* * *}$ & $9.14^{* * *}$ & 1.37 & 0.12 & $6.18^{* * *}$ \\
Error & 2 & 0.43 & 9.89 & 0.22 & 0.18 & 0.26 & 0.57 & 0.40 & 0.24 \\
\hline
\end{tabular}

$*, * *, * * *=$ significant at $p<0.5,0.1,0.05$. aType of coulter(C) bSeed rate(S) cNitrogen application(N) Emerg=Seed emergency 20 days after sowing, Prot $=$ Protein concentration, TOTE=relative amount total SDS-extractable proteins, TOTU=relative amount total SDS-unextractable proteins, \%LargeUPP=percentage of large unextractable polymeric protein in total large polymeric protein, $\% \mathrm{UPP}=$ percentage of total unextractable polymeric protein in total polymeric protein, $\mathrm{SMP}=$ small monomeric protein

Table 2. Mean values of yield, seed emergence, protein concentration and protein parameters on malt barley as influenced by type of coulter, seed rate and nitrogen application rate. Protein parameters are measured as relative areas of peaks in SE-HPLC chromatograms.

\begin{tabular}{lllllllllll}
\hline Coulter & $\begin{array}{l}\text { Seed } \\
\text { rate }\end{array}$ & Nitrogen & $\begin{array}{l}\text { Yield } \\
\text { Kg/ha }\end{array}$ & $\begin{array}{l}\text { Emerg } \\
\text { Plants/plot }\end{array}$ & $\begin{array}{l}\text { Prot } \\
\%\end{array}$ & TOTE & TOTU & \%LargeUPP & TUPP & SMP \\
\hline VR & Normal & Normal & $7030 \mathrm{a}$ & $37.2 \mathrm{~b}$ & 7030 & $8.39 \mathrm{a}$ & $3.30 \mathrm{~d}$ & $51.4 \mathrm{f}$ & $45.3 \mathrm{f}$ & $3.06 \mathrm{ab}$ \\
\hline VR & High & Normal & $6900 \mathrm{ab}$ & $42.8 \mathrm{a}$ & 6900 & $7.87 \mathrm{~b}$ & $3.49 \mathrm{c}$ & $52.7 \mathrm{e}$ & $48.4 \mathrm{e}$ & $3.12 \mathrm{ab}$ \\
\hline VR & Normal & No N & $4500 \mathrm{~d}$ & $36.9 \mathrm{~b}$ & 4500 & $6.52 \mathrm{c}$ & $2.85 \mathrm{f}$ & $52.9 \mathrm{~d}$ & $48.7 \mathrm{~d}$ & $2.56 \mathrm{c}$ \\
\hline TN & Normal & Normal & $6460 \mathrm{c}$ & $31.8 \mathrm{c}$ & 6460 & $8.51 \mathrm{a}$ & $3.98 \mathrm{a}$ & $60.6 \mathrm{a}$ & $54.2 \mathrm{a}$ & $3.29 \mathrm{a}$ \\
\hline TN & High & Normal & $6550 \mathrm{bc}$ & $34.1 \mathrm{bc}$ & 6550 & $7.75 \mathrm{~b}$ & $3.61 \mathrm{~b}$ & $53.8 \mathrm{c}$ & $49.4 \mathrm{c}$ & $2.97 \mathrm{~b}$ \\
\hline TN & Normal & No N & $4470 \mathrm{~d}$ & $36.1 \mathrm{~b}$ & 4470 & $6.41 \mathrm{c}$ & $2.99 \mathrm{e}$ & $54.1 \mathrm{~b}$ & $50.6 \mathrm{~b}$ & $2.57 \mathrm{c}$ \\
\hline
\end{tabular}

Coulter=type of coulter(C), Nitrogen=Nitrogen application rate, Emerg=Seed emergency 20 days after sowing, Prot= Protein concentration, TOTE=relative amount total SDS-extractable proteins, TOTU=relative amount total SDS-unextractable proteins, $\%$ LUPP $=$ percentage of large unextractable polymeric protein in total large polymeric protein, \%TUPP=percentage of total unextractable polymeric protein in total polymeric protein, $\mathrm{SMP}=$ small monomeric protein, $\mathrm{VR}=\mathrm{Väderstad} \mathrm{Rapid} \mathrm{Combi}$ Coulter, $\mathrm{TN}=$ Tume Nova Combi Coulter, No N=No nitrogen applied Means with the same letters within a column do not differ significantly (REGWQ 0.05 for yield and emergency and LSD 0.05 for protein factors) 
For small monomeric protein (SMP; both SDSextractable and SDS-unextractable) a relation was found with nitrogen application rate and the interaction between nitrogen application rate and seed rate (Table 1). The amount SMP increased with nitrogen applied compared to no nitrogen applied (Table 2).

\section{Discussion}

The present investigation showed that placement of fertilizer, by the use of different coulters, influenced yield, plant emergence and grain protein composition parameters in malting barley, while the grain protein concentration was not influenced.

Yield was only affected by fertilizer placement at normal seed rate. Thus, no significant differences in grain yield were detected due to fertilizer placement at high seed rate. At normal seed rate, the highest yield was obtained when the Väderstad Rapid Combi coulter was used, with fertilizer placement beside and deeper than the sown seeds as compared to the Tume Nova Combi coulter placing the fertilizer just below the sown seed. Fertilizer application direct below the sown seed have since long been known to increase the risk of burning the roots of the sown seeds, especially during dry conditions after sowing (Malhi et al., 2001). The risk of burning the roots of the sown seeds is one of the reasons why fertilizer application direct below the sown seeds has been avoided during the later years (Havlin et al., 1999). One indication of that the roots might have been burnt with fertilizer application direct below the sown seeds in the present investigation is that the seed emergence was influenced by the used fertilizer placement, i.e used coulter. Thus, for yield purposes, placement of fertilizer direct below the sown seeds should be avoided if the used application rate is not low enough to exclude the risk of damage. An increased seed rate might be one possible solution to compensate for the risk of burning the roots. However, in the present investigation, the increase in seed rate by $25 \%$ was not enough as compensation for the possible root burning.
This conclusion could be drawn since the yield of high seed rate and Tume Nova Combi coulter did not reach the yield of normal seed rate and Väderstad Rapid Combi coulter.

Despite the fact that the grain protein concentration did not differ significantly in malting barley when different fertilizer placements were used by use of different coulters, the protein composition was found to differ significantly. The relative amount of TOTU was found to be higher when fertilizer was placed below the sown seed with Tume Nova Combi coulter compared to when the fertilizer was placed beside and deeper than the sown seed through the use of Väderstad Rapid Combi coulter. Increased amount of TOTE and/or decreased amount of TOTU has in earlier studies on wheat, been related to later nitrogen availability compared to when the relative amount of TOTE is lower and/or of TOTU is higher (e.g. Johansson et al., 2004; 2005). The full nitrogen application was given at sowing in the present investigation. Also seed emergence was lower when the Tume Nova Combi coulter was used compared to when the Väderstad Rapid Combi coulter was used. Thus, nitrogen availability was higher for the young plants sown with the Tume Nova Combi coulter compared with the Väderstad Rapid Combi one. Thereby, it is possible to conclude that malting barley react similarly as bread wheat on early availability of nitrogen, i.e. with increased amount of TOTU and/or decreased amount of TOTE, compared with later availability of nitrogen. Increased amount of TOTE and/or decreased amount of TOTU has been correlated to weaker gluten strength in wheat compared to relatively lower amount of TOTE and/or higher amount of TOTU (Johansson et al., 2003). Increased protein concentration in malting barley has been related to a decrease in quality for beer production of that barley (Eagles et al., 1995; JinXin et al., 2006). If the amount of TOTE also influences the quality of malting barley has not been investigated so far.

The percentages of LargeUPP and UPP were both influenced by the use of different coulters, and thereby of placement of the fertilizer. The use of the Tume Nova Combi coulter, placing the fertilizer below the 
sown seed led to an increase in all three of them, thus generally indicating a more complex protein polymer structure compared to when the fertilizer was placed beside and deeper than the sown seed with the Väderstad Rapid Combi coulter. A more complex protein polymer structure influences the possibilities to break-down the protein polymers and to extract proteins (Kuktaite 2004). Furthermore, a higher proteins concentration, mostly correlated with a smaller or less complex protein structure, has been shown positively correlated to break-down rates of proteins during malting (Malik et al., 2012). Therefore, percentages of LargeUPP and UPP might be of importance for the beer quality of malting barley. For wheat, percentages of LargeUPP and UPP are positively correlated with gluten strength (e.g. Johansson et al., 2003, 2004).

So far, one of the most important type of proteins related to beer quality, is thought to be the $\mathrm{Z}$ proteins, influencing foaming (Evans and Hejgaard, 1999; Evans et al., 1999; Kaneko et al., 1999). The Z proteins are heat resistant albumins of serpin type (Evans and Hejgaard, 1999). Small proteins as albumins are normally found within the fraction called SMP (smaller monomeric protein) from the SE-HPLC chromatogram (Johansson et al., 2008). In the present investigation no differences in amount of SMP was found dependent on used coulter. Instead differences in amount of SMP were found dependent on use of fertiliser with a higher amount of SMP when fertilizer was applied. This is not in accordance with earlier findings for wheat (e.g. Johansson et al., 2004).

The application of nitrogen, in comparison with no nitrogen applied, influenced the yield, protein concentration and composition even more than the used coulter did. Nitrogen application increased both yield and protein concentration in comparison with no nitrogen applied. Similarly as has been found for wheat (e.g. Johansson et al., 2004), both TOTE and TOTU is increasing with nitrogen application. Normally in wheat, timing of nitrogen application seems to play a bigger role in determining percentages of LargeUPP and UPP than rate of nitrogen application
(Johansson et al., 2004). The results from the present study, with malting barley, showed similar results with no consistent changes in percentages of LargeUPP and UPP due to nitrogen application rate but a change in percentages of LargeUPP and UPP due to the used coulter implying differences in nitrogen placement and thereby nitrogen timing and availability.

\section{Conclusion}

Fertilizer placement just below the sown seed, with the use of the Tume Nova Combi coulter led to burning of the routs, and thereby to lower emergence rate and lower yield than placement beside and deeper than the sown seed as with the Väderstad Rapid Combi coulter. The lower emergence 20 days after sowing led to a higher nitrogen availability for each plant early during the growing season as nitrogen is applied at sowing with the Combi drill coulters. Similarly as have been found for wheat, early availability of nitrogen leads to a relatively higher amount of more polymerised proteins in the barley grain at harvest as compared to less nitrogen availability early during plant development. For wheat, protein polymerisation plays a role for bread baking quality, while it is not known weather protein polymerisation in barley is important for malting, brewing and beer quality.

\section{Acknowledgements}

This work was financed by the SL-stiftelsen and Partnerskap Alnarp.

\section{References}

Deibert, E. J., Lizotte, D. A., Bock, B. R. 1985. Wheat seed germination as influenced by fertilizer rate, fertilizer source, and spreader type with one-pass pneumatic seeding-fertilizing. North Dakota Farm Res. 42, 14-16. 
Eagles, H. A., Bedggood, A.G., Panozzo, J.F., Martin, P.J. 1995. Cultivar and environmental effects on malting quality in barley. Austr. J. Agric. Res. 46, 831-844.

Emgardsson, P. 2004a. Smart och spännande kombimaskin. Lantmannen. 7, 6-8.

Emgardsson, P. 2004b. Kombi utan gödselbillar. Lantmannen. 8, 32-33.

Evans, D.E., Hejgaard, J. 1999. The impact of malt derived proteins on beer foam quality. Part 1. The effect of germination and kilning on the level of protein Z4, protein Z7 and LTP1. J. Institute Brewing. 105, 159-169.

Evans D.E., Sheehan, M.C., Stewart, D.C. 1999. The impact of malt derived proteins on beer foam quality. Part II: The influence of malt foam-positive proteins and non-starch polysaccharides on beer foam quality. J. Institute Brewing. 105, 171-177.

Farrer, D.C., Weisz, R., Murphy, J.P., White, J.G. 2006. Minimizing protein variability in soft red winter wheat: impact of nitrogen application timing and rate. Agron. J. 98, 1137-1145.

Gupta, R.B., Khan, K., MacRitchie, F. 1993. Biochemical basis of flour properties in bread wheats. I. Effects of variation in the quantity and size distribution of polymeric protein. J. Cereal Sci. 18, 23-41.

Haby, L. 2006. Combi drilling without separate fertilizer bills Report 2006:1. The Swedish University of Agricultural Sciences. ISSN 1652-1552.

Havlin, J.L., Beaton, J.D., Tisdale, S.L., Nelson, W.L. 1999. Soil fertility and fertilizers: an introduction to nutrient management. New Jersey, 499 pp.

Howard K. A., Gayler, K.R., Eagles, H.A., Galloram, G.M. 1996. The relationship between $\mathrm{D}$ hordein and malting quality in barley. J. Cereal Sci. 24, 47-53.
International association of Cereal Chemistry 1980. Standard methods of the international association of cereal chemistry. Method 105 1. Detmold. Germany. ICC.

Jacobsen, J.S., Lorbeer, S.H., Houlton, H.A.R., Carlson, G.R. 1997. Reduced- till spring wheat response to fertilizer sources and placement methods. Comm. Soil Sci. Plant Anal. 28, 1237-1244.

JinXin, C., Fei, D., Kang, W., GuoPing, Z. 2006. Relationship between malt qualities and betaamylase activity and protein content as affected by timing of nitrogen fertilizer application. J. Zhejiang University. 7, 79-84.

Johansson, E., Svensson, G. 1999. Influences of yearly weather variation and fertilizer rate on bread-making quality in Swedish grown wheats containing HMW glutenin subunits $2+12$ or $5+10$ cultivated during the period 1990-96. J. Agric. Sci. Cambridge 132, 13-22.

Johansson, E., Prieto-Linde, M.L., Jönsson, J.Ö. 2001. Effect of wheat cultivar and nitrogen application on storage protein composition and bread-making quality. Cereal Chem. 78, 19-25.

Johansson, E., Prieto-Linde, M.L. Svensson, G., Jönsson, J.Ö. 2003. Influences of cultivar, cultivation year and fertilizer rate on amount of protein groups and amount and size distribution of mono- and polymeric proteins. J. Agric. Sci. 140, 275-284.

Johansson, E., Prieto-Linde, M.L., Svensson, G. 2004. Influence of nitrogen application rate and timing on grain protein composition and gluten strength in Swedish wheat cultivars. J. Plant Nutr. Soil Sci. 167, 345-350.

Johansson, E., Kuktaite, R., Andersson, A., PrietoLinde, M.L. 2005. Protein polymer built-up during wheat grain development: influences of temperature and nitrogen timing. J. Sci. Food Agric. 85, 473-479. 
Johansson, E., Prieto-Linde, M.L., Gissén, C. 2008. Influences of weather, cultivar and fertilizer rate on grain protein polymer accumulation in field grown winter wheat, and relations to grain water content and falling number.

Johansson, E., Malik, A.H., Hussain, A., Rasheed, F., Newson, W.R., Plivelic, T., Hedenqvist, M.S., Gällstedt, M., Kuktaite, R. 2013. Wheat gluten polymer structures: The impact of genotype, environment and processing on their functionality in various applications. Cereal Chem. 90, 367

Kaneko, T., Hirota, N., Yokoi, S., Kanatani, R., Ito, K. 1999. Molecular marker for protein $Z$ content in barley (Hordeum vulgare L.). Breed. Sci. 49, 6974.

Kuktaite, R. 2004. Protein quality in wheat: Changes in protein polymer composition during grain development and dough processing. Agraria 499, Swedish University of Agricultural Sciences, SLU Repro, Alnarp.

Kuktaite, R., Johansson, E., Juodeikiene, G. 2000. Composition and concentration of proteins in Lithuanian wheat cultivars: relationships with bread-making quality. Cereal Res. Commun. 28, 195-202.

Larroque, O.R., Gianibelli, M.C., Batey, I.L., MacRitchie, F. 1996. Identification of elution subfractions from the first peak in SE-HPLC chromatograms of wheat storage proteins. In: Wrigley C.W. (Ed.). Proc. 6th Int Gluten Workshop. Cereal Chemistry Division. Royal Australian Chemical Institute, North Melbourne, Australia. pp. 288-293.

Mahli, S.S., Grant, C.A., Johnston, A.M., Gill, K.S. 2001. Nitrogen fertilization management for notill cereal production in the Canadian Great Plains: a review. Soil Tillage Res. 60, 101-122.
Malik, A.H., Prieto-Linde, M.L., Kuktaite, R., Andersson, A., Johansson, E. 2011. Individual and interactive effects of cultivar maturation time, nitrogen regime and temperature level on accumulation of wheat grain proteins. J. Sci. Food Agric. 91,2192-2200.

Malik, A.H., Holm, L., Johansson, E. 2012. Soil and starter fertilizer and its effect on yield and protein composition of malting barley. J. Soil Sci. Plant Nutr. 12, 835-849.

Malik, A.H., Kuktaite, R., Johansson, E. 2013a. Combined effect of genetic and environmental factors on the accumulation of proteins in the wheat grain and their relationship to bread-making quality. J. Cereal Sci. 57, 170-174.

Malik, A.H., Holm, L., Kuktaite, R., Andersson, A. 2013b. Individual and combined effects of pre- and post-anthesis temperature on protein composition of two malting barley cultivars. J. Cereal Sci. 58, 341-347.

Malik, A.H., Holm, L., Johansson, E. 2013c. Governing plant development in barley (Hordeum vulgare L.): relation to protein composition and breakdown rates of protein polymers during malting. J. Sci. Food Agric.

McKenzie, R.H., Middleton, A.B., Bremer, E. 2005. Fertilization, seeding date, and seedling rate for malting barley yield and quality in southern Alberta. Can. J. Plant Sci. 85, 603-614.

Peltonen, J., Rita, H., Aikasalo, R., Home, S. 1994. Hordein and malting quality in orthern barleys. Hereditas. 120, 231-239.

Radford, B.J., Strong, W.M., Wilderminth, G.B. 1989. Effects of urea and flutriafol on germination, coleptile length and establishment of wheat and barley. Austr. J. Exp. Agric. 29, 551-557. 